\title{
Perbedaan teknik pencetakan two step dengan spacer coping metal dan polyethylene sheet terhadap cacat permukaan dan akurasi dimensi model kerja gigi tiruan cekat
}

\author{
Dicky Guntara $^{1 *}$, Putri Welda Utami Ritonga ${ }^{1}$ \\ ${ }^{1}$ Departemen Prostodontik, Fakultas Kedokteran Gigi, Universitas Sumatera Utara, Indonesia \\ *Korespondensi : godofdisicord@gmail.com \\ Submisi: 02 Oktober 2019; Penerimaan: 27 Oktober 2019; Publikasi Online: 31 Oktober 2019 \\ DOI: $10.24198 /$ pjdrs.v3i2.23798
}

\begin{abstract}
ABSTRAK
Pendahuluan: Pencetakan merupakan hasil dari cetakan gigi dan struktur jaringan pendukung. Untuk mendapatkan hasil cetakan yang baik, maka diperlukan teknik cetakan yang mampu menghasilkan permukaan cetakan yang halus dan akurasi dimensi yang tepat sehingga meningkatkan keberhasilan pembuatan gigi tiruan cekat. Salah satu teknik pencetakan untuk mendapatkan hasil cetakan yang baik adalah teknik two step dengan spacer. Tujuan penelitian ini untuk mengetahui cacat permukaan dan perbedaan nilai akurasi dimensi model kerja gigi tiruan cekat pada pencetakan two-step dengan spacer coping metal $1 \mathrm{~mm}$, coping metal 2 $\mathrm{mm}$, dan polyethylene sheet 0,5 mm. Metode: Sampel pada penelitian ini diperoleh dari pencetakan model induk berdasarkan spesifikasi ANSI/ADA No.19. Sampel tersebut diperlukan untuk melihat cacat permukaan dan perhitungan akurasi. Jumlah sampel yang akan digunakan untuk diberi perlakuan sebanyak 8 sampel setiap kelompok yaitu putty/wash two step unspacer (kelompok A), putty/wash two step spacer coping metal 1 mm (kelompok B), putty/wash two step spacer coping metal $2 \mathrm{~mm}$ (kelompok C), putty/wash two step spacer polyethylene sheet 0,5 mm (kelompok D). Hasil: Tidak ada perbedaan yang signifikan pada cacat permukaan cetakan dan ada perbedaan yang signifikan pada akurasi dimensi model kerja gigi tiruan cekat pada hasil pencetakan two step dengan spacer coping metal $1 \mathrm{~mm}$, coping metal $2 \mathrm{~mm}$, dan polyethylene sheet 0,5 mm. Simpulan: Bila dilihat dari cacat permukaan maka hasil pencetakan two step dengan spacer polyethylene sheet 0,5 mm yang paling baik digunakan. Bila dilihat dari akurasi dimensi maka pencetakan two step dengan spacer coping metal $2 \mathrm{~mm}$ yang paling baik digunakan.
\end{abstract}

Kata kunci: Pencetakan, two - step, spacer, cacat, akurasi.

\section{Difference between two step printing techniques with spacer coping metal and polyethylene sheet to surface defects and dimensional accuracy of fixed denture working models}

\begin{abstract}
Introduction: Imprint is the result of teeth and supporting tissue structures cast. To get a good impression, we need an imprint technique that can produce a smooth imprint surface and precise dimensional accuracy to increase the success of fixed denture manufacturing. One of the imprint technique to get a good impression is the two-step technique with a spacer. The purpose of this study was to determine surface defects and differences in dimensional accuracy value of fixed denture working models fabricated with two-step impression with $1 \mathrm{~mm}$ metal coping spacer, $2 \mathrm{~mm}$ metal coping sheet, and $0.5 \mathrm{~mm}$ polyethylene sheet. Methods: The sample in this study was obtained from the master model cast based on ANSI / ADA No.19 specifications. These samples were needed for surface defects observation and accuracy calculation. The number of samples that will be used for treatment was 8 samples per group, namely putty / wash two-step unspacer (group A), putty / wash two-step $1 \mathrm{~mm}$ metal coping spacer (group B), putty / wash two-step $2 \mathrm{~mm}$ metal coping spacer (group C), putty / wash two-step 0.5 $\mathrm{mm}$ polyethylene sheet spacer (group D). Results: There was no significant difference in the surface defects, and there were significant differences in dimensional accuracy of fixed denture working models fabricated with twostep imprint technique with $1 \mathrm{~mm}$ metal coping spacer, $2 \mathrm{~mm}$ metal coping spacer, and $0.5 \mathrm{~mm}$ polyethylene sheet. Conclusion: Assessed from the surface defects, two-step imprint technique with $0.5 \mathrm{~mm}$ polyethylene sheet is the best imprint technique. While from dimensional accuracy, two-step imprint technique with $2 \mathrm{~mm}$ metal coping spacer is the best imprint technique.
\end{abstract}

Keywords: Imprint, two-step, spacer, defect, accuracy. 


\section{PENDAHULUAN}

Salah satu prosedur penting dalam pembuatan gigi tiruan cekat adalah pencetakan yang akurat. ${ }^{1}$ Pencetakan merupakan hasil dari cetakan gigi dan struktur pendukung di sekitarnya., ${ }^{2,3}$ Pencetakan termasuk proses memindahkan keadaan jaringan lunak dan keras pasien ke laboratorium dan bagian terpenting dalam proses permbuatan gigi tiruan cekat. ${ }^{5}$ Tujuan dari pencetakan adalah menciptakan hasil cetakan yang bebas dari cacat pada hasil negatif dari preparasi gigi yang akan memengaruhi akurasi model kerja. Bagian ini penting untuk menghasilkan gigi tiruan memiliki bentuk serta fungsi yang baik. ${ }^{1}$

Beberapa tahun ini, bahan cetak silikon adisi (polyvinyl siloxanes) dilaporkan memiliki hasil yang akurat serta menghasilkan permukaan yang lebih halus. ${ }^{6}$ Hal ini dikarenakan kemampuan dalam mengkombinasikan physical property yang baik, mudah digunakan dan stabilitas dimensi yang baik. ${ }^{7,9}$ Silikon adisi dikenal sebagai bahan cetak yang baik karena stabilitas dimensinya, namun teknik pencetakan menjadi faktor yang memengaruhi akurasi dimensi. ${ }^{10}$ Menurut Hung, dkk pencetakan putty/wash direkomendasikan untuk mengatasi masalah shrinkage polimeritation pada silikon adisi. ${ }^{10}$

Kualitas pencetakan memiliki beberapa kriteria antara lain kemampuan dalam mendapatkan detail hasil yang baik, ada atau tidaknya gelembung udara, ada atau tidaknya robekan, daya alir yang baik. ${ }^{11}$ Beberapa faktor yang memengaruhi hasil cetakan yaitu hasil preparasi gigi, penanganan jaringan lunak, pemilihan sendok cetak, teknik pencetakan, bahan cetak, dan ketebalan bahan cetak. ${ }^{12}$ Akurasi dimensi masih merupakan masalah yang terjadi akhir - akhir ini. Lebih dari $89 \%$ hasil cetakan menghasilkan satu atau lebih hasil cetakan yang kurang akurat, ditambah lagi vikositas yang rendah pada material dan kontraksi yang tinggi pada saat polimerisasi akan mempengaruhi kualitas

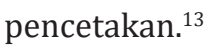

Baik one step maupun two step hanya wash saja yang harus menutupi keseluruhan preparasi, namun hal ini tidak dapat dihasilkan secara klinis. Teknik two step dengan spacer bahan wash dimasukan setelah putty mengalami polimerisasi dan kontraksi, dalam hal ini spacer yang digunakan dalam teknik two step berfungsi untuk menahan efek dari polimerisasi dan kontraksi pada putty. ${ }^{13}$ Pada pencetakan putty/ wash two step terdapat kemungkinan terjadinya ekspansi yang disebabkan karena ketika cetakan telah dilepas terjadi polimerisasi yang berlebihan sehingga akan menghasilkan model yang lebih kecil. Hal tersebut dapat diatasi dengan menggunakan spacer untuk mempersiapkan tempat wash sehingga meminimalisasi distorsi. ${ }^{14}$ Jenis bahan yang digunakan untuk spacer antara lain wax, cellophane strip, foil, coping metal dan polyethylene sheet.

Penelitian sebelumnya menunjukan hasil bahwa dalam meningkatkan kualitas hasil pencetakan pada permukaan secara detail lebih dipengaruhi oleh teknik pencetakan dibandingkan dengan bahan cetak. Penelitian sebelumnya juga menunjukan hasil bahwa teknik pencetakan tidak memengaruhi kualitas dari permukaan cetakan. ${ }^{1,15}$ Penelitian oleh Varvara Jeyapalan, dkk menunjukan pada teknik putty/wash two step memiliki cacat permukaan yang lebih sedikit dibanding dengan one step.$^{15}$ Berdasarkan penelitian Nafsani Fauzi pada pencetakan putty/wash two step jumlah cacat permukaan yang dihasilkan lebih sedikit dibanding dengan one step walau dalam hal ini tidak ada perbedaan yang signifikan. ${ }^{16} \mathrm{Hal}$ ini dihubungkan dengan tekanan yang diaplikasikan pada bahan cetak putty dengan bahan cetak wash yang mampu meningkatkan laju alir dan membantu dalam menghasilkan cetakan yang lebih tepat. ${ }^{1}$

Penelitian oleh Shrestha Prabhat, dkk menunjukkan teknik yang menggunakan spacer, udara yang terperangkap lebih banyak karena ruang untuk wash yang terlalu besar sehingga menyebabkan terbentuknya gelembung udara pada permukaan cetakan. ${ }^{17}$ Menurut penelitian Heidari Alireza, dkk terbentuknya bubble disebabkan oleh karena ketebalan spacer yang lebih dari $2 \mathrm{~mm} .^{18}$ Nissan Joseph, dkk merekomendasikan teknik two step untuk meningkatkan akurasi dimensi cetakan. ${ }^{19}$ Menurut Anshul Chug, dkk dan Nissan Joseph, dkk spacer coping metal dengan ketebalan $1 \mathrm{~mm}$ dan 2 $\mathrm{mm}$ mampu meningkatkan akurasi dimensi walau ada perbedaan signifkan dari penelitian tersebut. ${ }^{19,20}$ Menurut Nissan Joseph, dkk ada pengaruh spacer untuk meningkatkan akurasi dimensi pada cetakan. ${ }^{19}$ Menurut Hung Chugh, dkk tidak ada pengaruh terhadap penambahan spacer pada akurasi dimensi. ${ }^{14}$

Menurut Ramandeep Dugal, dkk spacer coping metal dengan ketebalan $1 \mathrm{~mm}$ memiliki akurasi dimensi yang paling baik karena bahan cetak wash yang terkontrol akan mengakibatkan sistem perlekatan yang baik antara putty dengan wash sehingga mengurangi terjadinya kontraksi 
dan polimerisasi terhadap bahan cetak. ${ }^{2}$ Menurut Kanmani, dkk spacer coping metal dengan ketebalan $2 \mathrm{~mm}$ memiliki akurasi dimensi yang paling baik, karena adanya bahan cetak wash yang terkontrol dapat mengimbangi akibat dari kontraksi pada wash terhadap dinding putty yang mengakibatkan model kerja menjadi mengecil terlihat pada daerah vertikal mengecil dan meluas kearah horizontal. ${ }^{4,20}$ Menurut Winston, dkk dan Shifra, dkk penggunaan polyethylene sheet sudah cukup untuk meningkatkan akurasi dimensi pada cetakan. ${ }^{21}$ Polyethylene sheet mampu menahan tekanan hidraulik yang besar dan akan meningkat jika bahan cetak wash diletakkan di atas hasil pencetakan bahan putty. ${ }^{22}$

Perbedaan pendapat penelitian - penelitian sebelumnya tentang pengaruh teknik pencetakan terutama penambahan spacer pada teknik pencetakan two - step terhadap kualitas pencetakan merupakan alasan peneliti tertarik untuk melakukan penelitian tersebut.

\section{METODE}

Metode penelitian yang digunakan adalah penelitian eksperimental labolatoris. Waktu penelitian dilakukan pada bulan mei - juli tahun 2018. Jumlah sampel yang akan digunakan untuk diberi perlakuan sebanyak 8 sampel setiap kelompok yaitu putty/wash two step unspacer (kelompok A), putty/wash two step spacer coping metal $1 \mathrm{~mm}$ (kelompok B), putty/ wash two step spacer coping metal $2 \mathrm{~mm}$ (kelompok C), putty/wash two step spacer polyethylene sheet 0,5 mm (kelompok D).

Lokasi pembuatan spacer coping metal dan sampel berada di unit jasa industry (UJI) dental FKG USU. Sampel pada penelitian ini diperoleh dari pencetakan model induk yang terdiri dari dua mahkota, preparasi abutment yang dibuat berdasarkan spesifikasi ANSI/ADA No.19 dengan tinggi $8,02 \mathrm{~mm}$, diameter $6,33 \mathrm{~mm}$ dan, jarak antara dua mahkota $28,25 \mathrm{~mm}$. Lokasi pembuatan model induk berada di fakultas teknik mesin USU. Persetujuan komisi etik tentang pelaksanaan penelitian kesehatan no:401/TGL/KEPK FK USURSUP HAM/2018.

Tahap awal adalah pembuatan sendok cetak fisiologis. Sendok cetak fisiologis pertama kali disiapkan dengan cara meletakan lembaran wax $2 \mathrm{~mm}$ diatas model induk yang digunakan, buatkan stopper pada daerah yang telah ditentukan sebesar
$2 \mathrm{~mm} \times 2 \mathrm{~mm}$ kemudian lapisi wax dengan resin akrilik swap polimerisasi, buatkan tankai sendok cetak yang terbuat dari resin akrilik, setelah resin mengeras lepaskan sendok cetak dari model induk, buang sisa - sisa wax, buatkan escape holes, dan haluskan.

Tahap berikutnya persiapan spacer polyethylene sheet yaitu dengan cara sendok cetak fisiologis diletakkan diatas lembaran polyethylene sheet, sesuaikan ukuran spacer polyethylene sheet dengan sendok cetak dan lebihkan $3 \mathrm{~cm}$, kemudian spacer polyethylene sheet digunting dan dirapikan sesuai ukuran yang sudah ditentukan. Tahap berikutnya pembuatan spacer coping metal yaitu dengan cara model kerja dioleskan hardener, spacer, dan vaseline, kemudian lakukan wax - up dan hasil wax - up diletakkan pada rubber sprue kemudian dipasangkan casting ring selanjutnya diisi dengan investment gips, casting ring dimasukan kedalam oven furnance selanjutnya dimasukkan kedalam alat casting untuk pengisian nickel - chromium, keluarkan coping dan dipoles.

Tahap berikutnya yaitu pembuatan sampel. Bahan cetak putty diaduk menggunakan tangan dan diletakkan pada sendok cetak fisiologis (kelompok A), spacer coping metal $1 \mathrm{~mm}$ (kelompok B), spacer coping metal $2 \mathrm{~mm}$ (kelompok C), spacer polyethylene sheet 0,5 mm (kelompok D) dipasangkan di antara bahan cetak putty dan abutment untuk mendapatkan ruang bagi bahan wash. Kemudian sendok cetak tersebut dicetakkan pada model induk. Sendok cetak dilepaskan dari model induk dan biarkan bahan puttyberpolimerisasi (kelompok A). Setelah itu spacer coping metal $1 \mathrm{~mm}$ (kelompok B), spacer coping metal $2 \mathrm{~mm}$ (kelompok C), spacer polyethylene sheet 0,5 mm (kelompok D) dilepas dari cetakan.

Bahan wash diaduk dengan menggunakan mixing gun kemudian lakukan pencetakan akhir dengan bahan wash yang ditempatkan pada hasil cetakan bahan cetak putty. Setelah bahan cetak wash dibiarkan selama 30 menit, agar bahan sampingan gelembung udara dapat keluar. ${ }^{17}$ Lepaskan cetakan dari model induk dan periksa permukaan hasil cetakan untuk menghitung jumlah cacat dengan kaca pembesar. Hasil cetakan diisi dengan dental stone type IV diatas vibrator. Setelah 30 menit model gips dilepaskan dari cetakan untuk mendapatkan model kerja. Kemudian setiap model kerja diukur dengan menggunakan kaliper digital. Waktu penelitian dimulai dari bulan mei hingga juli tahun 2018. Lokasi pembuatan model induk di fakultas teknik mesin 
USU dan lokasi pembuatan dan pengujian spacer dan sampel di unit jasa industri (UJI) dental FKG USU. Hasil cetakan permukaan abutment segera diperiksa setelah selesai dicetak oleh pemeriksa. Pemeriksa menghitung jumlah lubang berukuran kira-kira 2 $\mathrm{mm}-4 \mathrm{~mm}$ dan gelembung udara berukuran kirakira $<2 \mathrm{~mm}$ yang terlihat dengan mata dengan jarak sekitar 150mm untuk seluruh permukaan abutment dibantu dengan kaca pembesar.

Hanya cacat permukaan pada daerah abutment yang dihitung. Tipe cacat pada setiap spesimen digolongkan seperti tipe 0 tidak ada cacat; tipe 1 terdapat 1-2 gelembung udara; tipe 2 terdapat $>2$ gelembung udara; tipe 3 , terdapat adanya lubang. Sampel diletakkan diatas meja datar dan kemudian diurutkan berdasarkan nomor dan ditandai dengan spidol. Pengukuran akurasi dimensi dilakukan sebanyak tiga kali dengan menggunakan kaliper dan dengan mengukur: Bukolingual: diukur pada bukal dan lingual (depan tepi oklusal abutment ke belakang tepi oklusal abutment melewati titik tengah abutment); Oklusogingival: titik oklusal ke akhiran servikal; Interpreparasi: diukur dari groove (titik tengah) abutment I ke groove abutment II.

Uji statistik yang digunakan pada penelitian ini yaitu uji uni varian untuk melihat nilai rerata dan standart deviasi sampel. Uji Chi - square untuk mengetahui perbedaan pada variabel cacat permukaan. Uji One Way Anova dan Khruskal - Wallis untuk mengetahui perbedaan pada variable akurasi

\section{HASIL}

Gambar 1. Perhitungan akurasi dimensi dilihat secara oklusalgingiva, bukallingual dan interpreparasi.

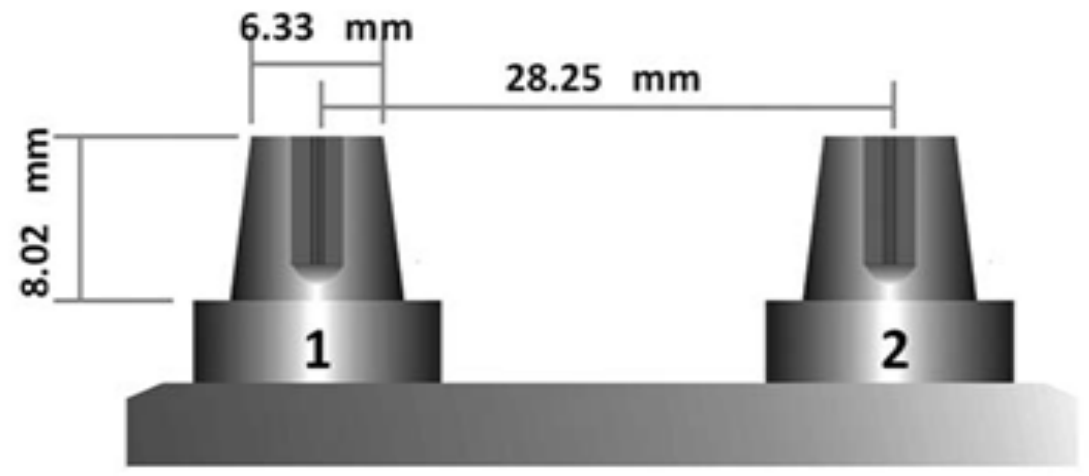

Tabel 1. Perbedaan cacat permukaan cetakan two - step.

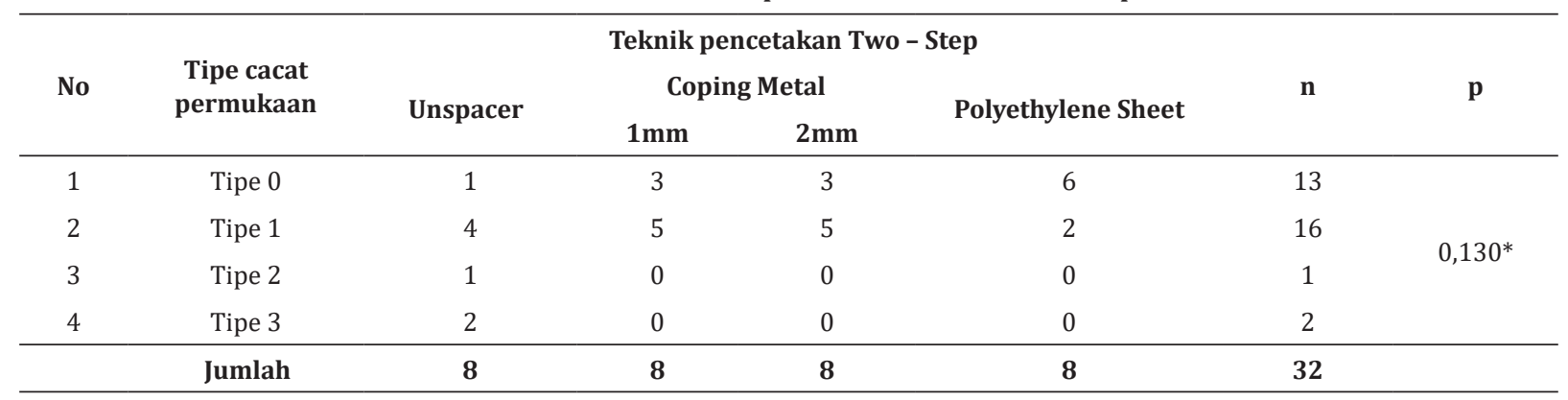

dimensi model kerja. Cacat permukaan cetakan putty/ wash two step unspacer dan dengan spacer coping metal $1 \mathrm{~mm}$, coping metal $2 \mathrm{~mm}$, dan polyethylene sheet $0,5 \mathrm{~mm}$ diketahui dengan menghitung jumlah gelembung udara dan lubang dibantu dengan kaca pembesar. Tabel 1 pencetakan putty/wash two step unspacer (kelompok A) cacat permukaan paling banyak adalah tipe 1 dengan jumlah 4 dan cacat permukaan paling sedikit adalah tipe 0 dan tipe 2 dengan masing - masing berjumlah 1 . Pencetakan putty/wash two - step spacer coping metal $1 \mathrm{~mm}$ (kelompok B) cacat permukaan paling banyak adalah tipe 1 dengan jumlah 5 dan cacat permukaan paling sedikit adalah tipe 2 dan 3 dengan masing masing berjumlah 0 . Pencetakan putty/wash two step spacer coping metal $2 \mathrm{~mm}$ (kelompok C) cacat permukaan 
paling banyak adalah tipe 1 dengan jumlah 5 dan cacat permukaan paling sedikit adalah tipe 2 dan 3 dengan masing masing berjumlah 0 . Pencetakan putty/wash two - step spacer polyethylene sheet 0,5 mm (kelompok D) cacat permukaan paling banyak adalah tipe 0 dengan jumlah 6 dan cacat permukaan paling sedikit adalah tipe 2 dan 3 dengan masing masing berjumlah 0 . Cacat permukaan paling sedikit terdapat pada kelompok D. Perbedaan cacat permukaan cetakan two step dengan spacer coping metal $1 \mathrm{~mm}$, coping metal $2 \mathrm{~mm}$, dan polyethylene sheet $0,5 \mathrm{~mm}$ diperloleh dari hasil uji statistik menggunakan uji analisis chi - square. Dari hasil uji analisis tersebut terlihat hasil didapati $\mathrm{p}=0,130$ $(\mathrm{p}>0,05)$ maka dapat disimpulkan tidak terdapat perbedaan pada jumlah tipe cacat permukaan dengan hasil pencetakan two - step dengan spacer coping metal $1 \mathrm{~mm}$, coping metal $2 \mathrm{~mm}$, dan polyethylene sheet $0,5 \mathrm{~mm}$ terlihat pada Tabel 1 .

Tabel 2. Perbedaan Akurasi Dimensi Model Kerja Gigi Tiruan Cekat Hasil Pencetakan Two - Step Pada Kelompok A, Kelompok B, Kelompok C, dan Kelompok D

Persentase Akurasi Dimensi

\begin{tabular}{|c|c|c|c|c|}
\hline \multirow{2}{*}{ Pengukuran } & \multirow[b]{2}{*}{ Perlakuan } & \multirow[b]{2}{*}{$\mathbf{N}$} & \multirow[b]{2}{*}{$\bar{X}_{ \pm \mathrm{SD}}$} & \multirow{2}{*}{$\mathbf{P}$} \\
\hline & & & & \\
\hline \multirow{4}{*}{ Interpreparasi } & $A$ & 8 & $\begin{array}{c}+0,015 \pm \\
0,001\end{array}$ & \multirow{4}{*}{$0,001^{*}$} \\
\hline & B & 8 & $\begin{array}{c}+0,010 \pm \\
0,003\end{array}$ & \\
\hline & C & 8 & $\begin{array}{c}+0,009 \pm \\
0,003\end{array}$ & \\
\hline & $D$ & 8 & $\begin{array}{c}+0,012 \pm \\
0,002\end{array}$ & \\
\hline \multirow{4}{*}{ Oklusogingiva } & $A$ & 8 & $\begin{array}{c}-0,021 \pm \\
0,004\end{array}$ & \multirow{4}{*}{$0,001^{*}$} \\
\hline & B & 8 & $\begin{array}{c}-0,005 \pm \\
0,002\end{array}$ & \\
\hline & C & 8 & $\begin{array}{c}-0,001 \pm \\
0,001\end{array}$ & \\
\hline & $D$ & 8 & $\begin{array}{c}-0,019 \pm \\
0,005\end{array}$ & \\
\hline \multirow{4}{*}{ Bukolingual } & $A$ & 8 & $\begin{array}{c}-0,021 \pm \\
0,004\end{array}$ & \multirow{4}{*}{$0,001^{*}$} \\
\hline & $B$ & 8 & $\begin{array}{c}-0,004_{ \pm} \\
0,001\end{array}$ & \\
\hline & C & 8 & $\begin{array}{c}-0,003_{ \pm} \\
0,001\end{array}$ & \\
\hline & $D$ & 8 & $\begin{array}{c}-0,017 \pm \\
0,003\end{array}$ & \\
\hline
\end{tabular}

\section{PEMBAHASAN}

Tabel 1 terlihat hasil cetakan putty/wash two step unspacer yang di dapati cacat permukaan paling banyak adalah tipe 1 dengan jumlah 4 dan cacat permukaan paling sedikit tipe 0 dan tipe 2 dengan masing masing berjumlah 1 . Pada pencetakan putty/ wash two step spacer coping metal $1 \mathrm{~mm}$ permukaan paling banyak adalah tipe 1 dengan jumlah 5 dan cacat permukaan paling sedikit adalah tipe 2 dan 3 dengan masing masing berjumlah 0 .

Pada pencetakan putty/wash two step spacer coping metal $2 \mathrm{~mm}$ cacat permukaan paling banyak adalah tipe 1 dengan jumlah 5 dan cacat permukaan paling sedikit adalah tipe 2 dan 3 dengan masing masing berjumlah 0 . Pada pencetakan putty/wash two step spacer polyethylene sheet $0,5 \mathrm{~mm}$ cacat permukaan paling banyak adalah tipe 0 dengan jumlah 6 dan cacat permukaan paling sedikit adalah tipe 2 dan 3 dengan masing masing berjumlah 0 .

Hasil penelitian ini sesuai dengan penelitian Varvara yang menyatakan cacat permukaan pada teknik yang menggunakan spacer lebih sedikit dibanding tanpa spacer. ${ }^{15}$ Hasil penelitian ini tidak sesuai dengan hasil Shrestha yang menyatakan bahwa teknik two step unspacer memiliki cacat permukaan yang lebih sedikit dibanding dengan two step dengan spacer ${ }^{17}$ Hal ini bisa dikarenakan perbedaan dari pengadukan bahan wash dimana pada penelitian ini pengadukan bahan wash dengan mixing gun sehingga memberikan hasil yang lebih baik dibanding dengan pengadukan secara manual. Pengadukan secara manual memungkinkan gelembung udara yang terjebak lebih banyak dibandingkan dengan mixing gun. ${ }^{17}$ Selain itu dengan adanya spacer terdapat ruang agar gelembung udara dapat dengan mudah keluar. $^{15}$

Ditemukan dalam tipe cacat permukaan pada putty/wash two step coping metal $1 \mathrm{~mm}$ dan $2 \mathrm{~mm}$ dengan polyethylene sheet $0,5 \mathrm{~mm}$, kemungkinan disebabkan karena adanya perbedaan ruang untuk bahan wash yang terlalu besar sehingga menyebabkan terbentuknya gelembung udara pada permukaan cetakan. Hasil ini sesuai dengan penelitian Shrestha dkk menyatakan pada pencetakan menggunakan spacer sebesar $1 \mathrm{~mm}$ dan $2 \mathrm{~mm}$ sering menyebabkan gelembung udara yang terbentuk lebih banyak. ${ }^{17}$

Jenis bahan spacer juga memengaruhi karena spacer yang elastis seperti polyethylene sheet mampu memberikan ruang untuk bahan wash tidak berlebihan sehingga menyebabkan gelembung 
udara lebih susah terperangkap dibanding dengan bahan spacer yang cenderung kaku. ${ }^{17,18}$ Tabel 1 memperlihatkan hasil uji analisis chi - square $\mathrm{p}$ $=0,130(\mathrm{p}>0,05)$ maka dapat disimpulkan tidak terdapat perbedaan pada cacat permukaan dengan hasil pencetakan two step unspacer dan dengan spacer coping metal $1 \mathrm{~mm}$, coping metal $2 \mathrm{~mm}$, dan polyethylene sheet $0,5 \mathrm{~mm}$.

Penelitian ini sesuai dengan penelitian Shrestha yang menyatakan tidak ada perbedaan yang signifikan terhadap cacat permukaan baik dengan teknik menggunakan spacer maupun tanpa spacer. ${ }^{17} \mathrm{Hal}$ ini dihubungkan dengan tekanan yang diaplikasikan pada bahan putty dengan bahan cetak wash mampu meningkatkan laju alir dan membantu dalam menghasilkan cetakan yang bebas dari cacat. ${ }^{15}$ Tidak adanya perbedaan pada penelitian ini bisa disebabkan karena jumlah sampel yang tidak banyak sehingga perbedaan yang didapati juga tidak terlihat jika dianalisis dengan statistik. Kemungkinan lainya adalah ketika pengadukan, terjadi reaksi adisi dan terjadi juga proses crosslinking dari vinyl terminated polydimethyl siloxane yang dikatalis oleh garam platinum (asam kloroplatina).

Gas hidrogen merupakan hasil sampingan dari reaksi polimerisasi tersebut sehingga menyebabkan terbentuk bubble. ${ }^{23}$ Kesimpulan pada penelitian ini sependapat dengan penelitia Nafsani yang menyatakan tidak ada perbedaan cacat permukaan berdasarkan teknik pencetakan. ${ }^{16}$ Serta sependapat dengan penelitian Sherstha yang menyatakan tidak adanya perbedaan yang signifikan terhadap cacat permukaan baik yang menggunakan spacer maupun tanpa spacer. ${ }^{17}$

Tabel 2 menunjukan nilai presentasi akurasi dimensi untuk OG memiliki hasil negatif untuk BL semua sampel menghasilkan nilai negatif, dan untuk IP semua sampel menghasilkan nilai positif. Dari hasil tabel tersebut terlihat semua model kerja terjadi perubahan akurasi dimensi yaitu ukuran model kerja menjadi lebih kecil dari ukuran model induk. Hal ini terjadi dikarenakan pada pencetakan putty/wash two step terdapat kemungkinan terjadinya ekspansi disebabkan karena ketika cetakan telah dilepas terjadi polimerisasi yang berlebihan sehingga menghasilkan model kerja yang lebih kecil. ${ }^{14}$

Penelitian Nissan dkk menunjukkan hal yang sama dimana dilihat dari aspek intraabutment yaitu pada daerah oklusogingiva dan bukolingual terjadi pengurangan ukuran dan jika dilihat dari aspek interabutment yaitu daerah interpreparasi terjadi penambahan ukuran model. Kemungkinan hal ini terjadi karena kontraksi dari dinding sendok cetak menyebabkan terjadinya pengerutan dari segala aspek pada abutment sehingga ukuran dari abutment menjadi mengecil dan menyebabkan penambahan ukuran pada daerah interpreparasi, akibatnya ukuran dari model kerja menjadi lebih kecil dari ukuran model induk. ${ }^{19}$

Tabel 2 rerata dan standard deviasi dari persentase akurasi dimensi terkecil terdapat pada kelompok C dimana diukur dari OG adalah $-0,001 \pm 0,001$, diukur dari BL adalah $-0,003 \pm 0,001$, dan diukur dari IP adalah $+0,009 \pm 0,001$. Rerata dan standard deviasi dari persentase akurasi dimensi terbesar terdapat pada kelompok A dimana diukur dari OG adalah $-0,021 \pm 0,004$, diukur dari BL adalah $-0,021 \pm 0,004$, dan diukur dari IP adalah $+0,015 \pm 0,016$. Hal ini dikarenakan pengaruh dari ketebalan dari wash dimana dari hasil penelitian ini wash dengan ketebalan $2 \mathrm{~mm}$ memiliki hasil yang paling bagus dan mampu menahan ekspansi yang terjadi pada bahan cetak wash. Hal ini terjadi karena spacer coping metal $2 \mathrm{~mm}$ mampu menahan adanya kontraksi dari bahan cetak ke dinding sendok cetak yang menyebabkan terjadinya pengerutan dari segala aspek pada abutment. ${ }^{19}$

Perbedaan jenis spacer yang digunakan juga memiliki pengaruh dimana bahan spacer yang elastis seperti polyethylene sheet cenderung lebih susah dalam mengontrol ketebalan wash secara keseluruhan dibanding dengan jenis spacer yang kaku seperti coping metal. ${ }^{15,19}$ Perbedaan akurasi dimensi model kerja dilakukan uji one way anova dan uji kruskal - wallis. Terlihat pada Tabel 2 pengukuran interpreparasi diperoleh nilai $\mathrm{p}=0,001(\mathrm{p}<0,05)$ maka disimpulkan adanya perbedaan yang signifikan di antara kelompok pencetakan putty/wash two step unspacer, spacer coping metal $1 \mathrm{~mm}$, spacer coping metal $2 \mathrm{~mm}$, dan polyethylene sheet $0,5 \mathrm{~mm}$.

Data pengukuran oklusogingiva diperoleh nilai $\mathrm{p}=0,001(\mathrm{p}<0,05)$ maka disimpulkan terdapat perbedaan yang signifikan antara kelompok pencetakan putty/wash two step unspacer, pencetakan spacer coping metal $1 \mathrm{~mm}$, spacer coping metal $2 \mathrm{~mm}$, dan spacer polyethylene sheet $0,5 \mathrm{~mm}$. Pengukuran bukolingual diperoleh nilai $\mathrm{p}=0,001 \mathrm{c}$ $<0,05)$ maka disimpulkan terdapat perbedaan yang signifikan antara kelompok pencetakan putty/wash two step unspacer, pencetakan spacer coping metal 
$1 \mathrm{~mm}$, coping metal $2 \mathrm{~mm}$, dan polyethylene sheet $0,5 \mathrm{~mm}$. Tabel 2 terlihat bahwa terjadi pengurangan ukuran model kerja pada tiap kelompok pencetakan. Jika dilihat akurasi dimensi dari persentase deviasi kelompok pencetakan putty/wash two step spacer coping metal $2 \mathrm{~mm}$ mengalami perubahan paling kecil dari aspek oklusalgingiva, bukolingual dan interpreparasi.

Penelitian ini sesuai dengan penelitian Kanmani dkk yang menyatakan spacer coping metal $2 \mathrm{~mm}$ memiliki perubahan akurasi dimensi yang paling kecil dibandingkan dengan spacer yang lain. Penelitian Nissan menyatakan spacer coping metal 2 $\mathrm{mm}$ mampu menahan pengurangan atau pengecilan model kerja yang dilihat dari aspek intraabutment terjadi pengurangan ukuran dan jika dilihat dari aspek interabutment terjadi penambahan ukuran yang mengakibatkan ukuran model kerja menjadi lebih kecil dibanding model induk. Hal ini terjadi karena spacer coping metal $2 \mathrm{~mm}$ mampu menahan adanya kontraksi dari bahan cetak ke dinding sendok cetak yang menyebabkan terjadinya pengerutan dari segala aspek pada abutment. ${ }^{19}$

Perbedaan dari hasil penelitian tersebut juga terjadi karena perbedaan dari bahan atau jenis spacer yang digunakan. Bahan spacer yang elastis seperti polyethylene sheet cenderung susah dalam mengontrol ketebalan wash secara keseluruhan dibanding dengan jenis spacer yang kaku seperti coping metal. ${ }^{15,19}$ Reaksi yang terjadi pada dental stone type IV juga memengaruhi akurasi dimensi. Ketika hemihydrate bercampur dengan air, hasil yang didapatkan adalah dalam bentuk cair karena hemihydrate akan larut hingga membentuk larutan yang terdiri dari ion $\mathrm{Ca}^{2+}$ dan $\left(\mathrm{SO}_{4}\right)^{2-}$.

Larutan inilah yang akan membentuk dihydrate.Selama dihydrate mengalami pengendapan, sisa - sisa hemihydrate akan terus larut. Proses inilah akan membentuk kristal baru atau membuat kristal yang sudah terbentuk membesar hingga tidak ada lagi dihydrate yang dapat mengendap. Kristal - kristal yang berasal dari dihydrate akan membesar sehingga membuat terjadinya ekspansi pada dental stone. Ekspansi pada dental stone cenderung menyebabkan terjadinya perubahan dimensi walau hanya berkisar $0,06 \%-0,5 \%{ }^{14}$

Pencetakan putty/wash two step spacer coping metal $2 \mathrm{~mm}$ memiliki hasil yang lebih baik. Hasil penelitian ini berbeda dengan pernyataan Hung dkk yang menyatakan tidak ada pengaruh penambahan spacer pada akurasi dimensi. ${ }^{10}$ Hasil penelitian ini sesuai dengan pendapat dari Kanmani dkk yang menyatakan pencetakan putty/wash two - step spacer coping metal dengan ketebalan $2 \mathrm{~mm}$ memiliki hasil akurasi dimensi yang paling baik. ${ }^{4}$ Selain ini hasil penelitian ini juga sesuai dengan pendapat dari Nissan dkk tentang adanya pengaruh spacer untuk meningkatkan akurasi dimensi pada model kerja karena spacer mampu mempersiapkan tempat bagi bahan wash agar ketebalan cetakan dapat terkontrol sehingga meminimalisasi distorsi yang terjadi. ${ }^{19}$

Kelemahan pada penelitian ini adalah arah membuka cetakan yang tidak bisa dikendalikan sehingga terjadi defleksi saat membuka cetakan. Serta alat yang digunakan untuk memeriksa cacat permukaan dan akurasi dimensi adalah kaca pembesar dan kaliper digital yang memiliki kemungkinan besar terjadinya human error saat operator mengalami kelelahan. Dapat disarankan untuk menggunakan 3D scanner laser untuk menghitung akurasi dimensi dan microscope untuk melihat cacat permukaan.

\section{SIMPULAN}

Terdapat dua variabel pada penelitian ini yaitu variable cacat permukaan dan akurasi dimensi. Variabel cacat permukaan, pencetakan two - step dengan spacer polyethylene sheet $0,5 \mathrm{~mm}$ yang paling baik digunakan. Variabel akurasi dimensi, pencetakan two - step dengan spacer coping metal $2 \mathrm{~mm}$ yang paling baik digunakan.

Tidak ada perbedaan pencetakan two - step dengan spacer coping metal $1 \mathrm{~mm}$, coping metal $2 \mathrm{~mm}$, dan polyethylene sheet $0,5 \mathrm{~mm}$, dan unspacer terhadap cacat permukaan cetakan. Ada perbedaan yang signifikan pada pencetakan two - step dengan spacer coping metal $1 \mathrm{~mm}$, coping metal $2 \mathrm{~mm}$, dan polyethylene sheet $0,5 \mathrm{~mm}$ dan unspacer terhadap akurasi dimensi model kerja gigi tiruan cekat.

\section{DAFTAR PUSTAKA}

1. Varvara G, Murura G, Sinjari B, Cardelli P, Caputi S. Evaluation of defects in surface detail for monophase, 2 - phase, and 3 - phase impression technique: An in vitro study. J Prosthet Dent. 2015; 113: 108 - 12 .

2. Dugal R, Railkar B, Musani S. Commparative evaluation of dimensional accuracy of different 
polyvinyl siloxane putty - wash impression technique - in vitro study. J Int Oral Health 2013; 5(5): $85-6,91-3$.

3. Pandey A, Mehtra A. Comparative study of dimensional stability and accuracy of various elastomeric materials. Jornal of Dental and Medical Sciences 2014; 13: 40, 43.

4. M. Kanmani, C. Sabarigirinathan, K. Vinayagavel, V. Harisnath, P. Rupkumar, Bipinchandra LN, et al. The influence of putty wash impression technique on dimensional accuracy of twi commercially available vinyl poly siloxane impression materials: An invitro study. Int J Dent Health Sci 2015; 2(3): $473-4,478-9$.

5. Jamshidy L, Mozaffari HR, Faraji P, Sharifi R. Accuracy of the one - stage and two - stage impression technique: A comparative analysis. International Journal of Dentistry 2016; 2016: $1-4$.

6. Singh K, Sahoo S, KD Prasad, Goel M, Singh A. Effect of different impression technique on the dimensional accuracy of impressions using various elastomeric impression materials: An in vitro study. J Contemp Dent Pract 2012; 13(1): 98.

7. Goel M, Dhawan P, Tandan P, Madhukar P. Need for a reliable alternative to custom - made implant impression tray: an in vitro study comparing accuracy of custom tray vesus specialized aluminum stock tray. J Indian Prosthodont Soc 2018; 18: $271-6$.

8. Levartovsky S, Levy G, Brosh T, Harel N, Ganor Y, Pilo R. Dimensional stability of polyvinyl siloxane impression material reproducing the sulcular area. Dent Mater J 2013; 32(1): 25 - 6, 29 - 31.

9. Shiozawa M, Takahashi H, Finger WJ, Iwasaki N. Effects of the space for wash materials on sulcus depth reproduction with addition - curing silicone using two - step putty - wash technique. Dent Mater J 2013; 32(1): 150.

10. Franco EB, Leonardo FdC, Herrera FS, Benetti AR. Accuracy of single - step versus 2 - step double mix - impression technique. ISRN Dentistry 2011; 2011: 1 - 4 .

11. Saifudin ASAZ, Kamaruddin F, Ghani SMA. The quality of working impressions for the fabrication of fixed prosthodontics prostheses (crown and bridge ). European Journal of Generl Dentistry 2014; 3 (2): 00 - 01.

12. Vitti RP, Sobrinho LC, Sinhoreti MAC. Dimensional accuracy of stone cast made by a monophase impression technique using different elastomeric impression materials. Braz J Oral Sci 2011; 10 (3): $175-9$.

13. Kumari N, Nandeeshwar DB. The dimensional accuracy of polyvinyl siloxane impression materials using two different impression technique: an in vitro study. J indian Prosthodont Soc 2015; 15: 211 - 7.

14. Kenneth AJ, Shen C, Rawls HR. Phillips' science of dental materials. 12 th ed., Riverport lane: Elsevier Saunders. 2013: 160.

15. Varvara G, Murmura G, Sinjari B, Cardeli P, Caputi S. Evaluation of defects in survace detail for monophase, 2 - phase, and 3 - phase impression technique: An invitro study. J Prosthet Dent 2014: $1-4$

16. Fauzia N. Pengaruh pencetakan putty/wash one - step dan two - step terhadap cacat permukaan cetakan dan akurasi dimensi model kerja gigi tiruan cekat. Skripsi. USU. Medan. 2017.

17. Shrestha P, Poudel S, Shrestha K. A clinical comparison of polyvinyl siloxane impressions for fixed partial dentures using three different techniques. Journal of Advanced Medical and Dental Sciences Research. 2015; 3(2): 6.

18. Heidari B, Fallahi S, Izadi A, dkk. Experimental investigation of effect of light - body material space on the accuracy of cast resulting of two step impression technique in two types of addition silicone. IJBPAS 2016; 5(9): 3320 - 330.

19. Nissan J, Rosner O, Bukhari MA, Ghelfan O, Pilo R. Effect of various putty - wash impression techniques on marginal fit of cast crowns. Int J Periodontics Restorative Dent 2013; 33: e37 e41.

20. Chugh A, Arora A, Singh VP. Accuracy of different putty - wash impression techniques with various spacer thickness. Int J Clin Pediatr Dent 2012; 5(1): $33-7$.

21. Levartovsky S, Levy G, Brosh T, Harel N, Ganor Y, Pilo R. Dimensional stability of polyvinyl siloxane impression material reproducing the sulcular area. Dent Mater J 2013; 32(1): 25 - 6, 29 - 31.

22. McCabe JF, Walls AWG. Bahan kedokteran gigi. Ahli Bahasa. Sunarintyas S, Mustaqimah ND. Jakarta: EGC, 2014: 194, 196 - 7, 229 - 32, 234 -42 .

23. Fernando. Perbedaan akurasi dimensi hasil pencetakan teknik putty - wash satu tahap dan 
dua tahap dalam pembuatan gigi tiruan cekat. Tesis. Medan: Program Pendidikan Dokter Gigi
Spesialis Prostodonsia Fakultas Kedokteran Gigi Universitas Sumatera Utara. 2017: 26 - 27. 